\title{
2117 アルミニウム合金製大径リベットの開発とその強度特性
}

\author{
萩澤 亘保 $*$. 大倉 一郎** \\ 岩田 節雄 $* * *$. 北村 幸嗣 $* * * *$
}

Journal of Japan Institute of Light Metals, Vol. 56, No. 8 (2006), pp. 441-447

\section{Development of 2117 aluminum alloy rivets of large diameter and their strength properties}

\author{
Nobuyasu HAGISAWA*, Ichiro OKURA** \\ Setsuo IWATA ${ }^{* * *}$ and Koji KITAMURA****
}

\begin{abstract}
In this study, 2117 aluminum alloy rivets of large diameter are produced and investigated on the properties of strength of them. Extruded round bars are used for the rivets of $22 \mathrm{~mm}$ in nominal diameter. First, the forming and heat treatment conditions not so as to generate large grains in the section of the rivets are examined. Next, it is shown that by pressing under cold condition the end of the shank of the rivets into the flat head of $32 \mathrm{~mm}$ in diameter and $10 \mathrm{~mm}$ in height, the hole of $22.8 \mathrm{~mm}$ in diameter is full of the rivet. The static loading and fatigue tests for the joints fabricated by the developed rivets provide the shear strength and the fatigue strength in shear of the rivets.
\end{abstract}

(Received January 30, 2006 Accepted May 2, 2006)

Keywords: rivet, 2117 aluminum alloy, shear strength, fatigue strength

\section{1.はじめに}

平成 5 年に改正された道路構造令第 35 条の設計自動車荷 重の $196 \mathrm{kN}$ から $245 \mathrm{kN}$ への変更に伴い，既存橋の補強対策 が進められている。この有効な対策の一つとして，コンク リート床版を，軽量なアルミニウム合金製床版で取り替える ことにより，自動車荷重の増加分と相殺させることが考えら れる ${ }^{1)}$ 。また，ライフサイクルコストを重視する近年の傾向 から維持管理コストが少なくてすむアルミニウム橋，その他， アルミニウム社会基盤構造物が検討されている。しかし，こ れらの補強対策や構造物を建設するためには，アルミニウム 合金部材の接合問題を避けて通ることができない。

アルミニウム合金部材の接合には，MIG 溶接，摩擦擋拌接 合，およびボルトやリベットなどの機械的接合がある。この 中でも MIG 溶接が広く用いられてきたが，MIG 溶接の疲労 強度は非常に低いことが知られている。そのため，著者らは 摩擦擋拌接合で製作されたアルミニウム床版の疲労特性に関 する研究を実施し, 摩擦擋拌接合部の疲労強度が MIG 溶接 部のそれよりも格段に高いことを示した ${ }^{2)}$ 。摩擦擋拌接合は, 長尺なアルミニウム合金部材を平行に並べ，それらの長辺同 士を長手方向に接合するには有効な接合法である。しかし， 接合装置の能力から，平行に並べるアルミニウム合金部材の 数は制限される。この対策として，摩擦攪拌接合で製造され
たブロックをリベットで接合して組立てていく方法が考えら れる。リベットに使用する材料として，鋼ではなくてアルミ ニウム合金を用いることによって異種金属接触腐食を回避す ることができる。

橋や社会基盤構造物は大型であり, 作用荷重が大きいた め, 部材を接合するリベットには, 直径が $22 \mathrm{~mm}$ 程度の大径 のものが要求される。しかし，そのような大径のアルミニウ ム合金製リベットの事例は，これまで見られない。

本研究では, 社会基盤構造物に適用できる大径 $22 \mathrm{~mm}$ のア ルミニウム合金製リベットを開発し，従来，鋼リベットの現 場接合で用いられていた，リベットの加熱後にリベッティン グハンマでかしめ成形する方法ではなく，プレス機を用いた 冷間成形によるかしめ方法が可能であることを示した。また， 試作したアルミニウム合金製リベットを用いて作製した継手 試験片の引張試験および疲労試験からリベットのせん断強さ とせん断疲労強度を明らかにした。

\section{2. アルミニウム合金製リベットの製作}

\section{1 アルミニウム合金製リベット材}

リベットは，棒の片方の端に頭を成形し，被接合部材に開 けられた孔に他方の端を通し，反対側に突出した棒の端を圧 縮してかしめ頭を成形することにより部材を接合するむので ある。被接合部材に開けられた孔は，リベットの軸径より大

*日本軽金属(森)゙ループ技術センター（テ 421-3291＼cjkstart静岡県静岡市清水区蒲原 1-34-1）。 Research \& Development Center, Nippon Light Metal Company, Ltd. (1-34-1 Kambara, Shimizu-ku, Shizuoka-shi, Shizuoka 421-3291).

**大 大阪大学大学院工学研究科地球総合工学専攻（吹田市）。Osaka University, Graduate School of Engineering, Department of Civil Engineering (Suita-shi, Osaka).

**** 金沢工業大学工学実技教育（石川郡）。Kanazawa Institute of Technology, Fundamental Laboratory for Engineering Education（Ishikawa-gun, Ishikawa).

*****立造船(侏技術研究所（大阪市)。Technical Research Institute, Hitachi Zosen Corporation（Osaka-shi, Osaka）. 
Table 1 Chemical compositions of aluminum alloys for rivet (mass \%)

\begin{tabular}{|c|c|c|c|c|c|c|c|c|c|}
\hline \multicolumn{2}{|c|}{ Aluminum alloy } & $\mathrm{Si}$ & $\mathrm{Fe}$ & $\mathrm{Cu}$ & Mn & $\mathrm{Mg}$ & $\mathrm{Cr}$ & $\mathrm{Zn}$ & $\mathrm{Ti}$ \\
\hline A2117 & $\begin{array}{c}\text { JIS } \\
\text { Measured }\end{array}$ & $\begin{array}{l}\leqq 0.8 \\
0.31\end{array}$ & $\begin{array}{l}\leqq 0.7 \\
0.15\end{array}$ & $\begin{array}{c}2.2 \sim 3.0 \\
2.5\end{array}$ & $\begin{array}{l}\leqq 0.20 \\
\leqq 0.01\end{array}$ & $\begin{array}{c}0.20 \sim 0.50 \\
0.34\end{array}$ & $\begin{array}{l}\leqq 0.10 \\
\leqq 0.01\end{array}$ & $\begin{array}{l}\leqq 0.25 \\
\leqq 0.01\end{array}$ & $\begin{array}{l}\leqq 0.05 \\
\leqq 0.01\end{array}$ \\
\hline $\begin{array}{l}\text { A5056 } \\
\text { A5N02 } \\
\text { A6061 }\end{array}$ & $\begin{array}{l}\text { JIS } \\
\text { JIS } \\
\text { JIS }\end{array}$ & $\begin{array}{c}\leqq 0.30 \\
\leqq 0.40 \\
0.40 \sim 0.8\end{array}$ & $\begin{array}{l}\leqq 0.40 \\
\leqq 0.40 \\
\leqq 0.7\end{array}$ & $\begin{array}{c}\leqq 0.10 \\
\leqq 0.10 \\
0.15 \sim 0.40\end{array}$ & $\begin{array}{c}0.05 \sim 0.20 \\
0.30 \sim 1.0 \\
\leqq 0.15\end{array}$ & $\begin{array}{l}4.5 \sim 5.6 \\
3.0 \sim 4.0 \\
0.8 \sim 1.2\end{array}$ & $\begin{array}{c}0.05 \sim 0.20 \\
\leqq 0.50 \\
0.04 \sim 0.35\end{array}$ & $\begin{array}{l}\leqq 0.10 \\
\leqq 0.10 \\
\leqq 0.25\end{array}$ & $\begin{array}{l}\leqq 0.05 \\
\leqq 0.20 \\
\leqq 0.15\end{array}$ \\
\hline
\end{tabular}

Table 2 Mechanical properties of aluminum alloys for rivet

\begin{tabular}{|c|c|c|c|c|c|c|}
\hline \multicolumn{3}{|c|}{ Aluminum alloy } & \multirow{2}{*}{$\begin{array}{c}\text { Diameter } d(\mathrm{~mm}) \\
d=22 \\
3<d \leqq 10\end{array}$} & \multirow{2}{*}{$\begin{array}{l}\text { Tensile strength } \\
\text { (MPa) } \\
307 \\
\geqq 265\end{array}$} & \multirow{2}{*}{$\begin{array}{c}0.2 \% \text { proof stress } \\
(\mathrm{MPa})\end{array}$} & \multirow{2}{*}{$\begin{array}{c}\text { Elongation } \\
\quad(\%) \\
34 \\
\geqq 18\end{array}$} \\
\hline $\begin{array}{l}\text { A2117-T4 } \\
\text { A2117-T4 }\end{array}$ & $\begin{array}{l}\text { Bar } \\
\text { Wire }\end{array}$ & $\begin{array}{l}\text { Measured } \\
\text { JIS H } 4040\end{array}$ & & & & \\
\hline \multicolumn{2}{|c|}{$\begin{array}{l}\text { A5056BD-O } \\
\text { A5N02BD-O } \\
\text { A6061BD-T6 }\end{array}$} & $\begin{array}{l}\text { JIS H } 4040 \\
\text { JIS H } 4040 \\
\text { JIS H } 4040\end{array}$ & $\begin{array}{c}3<d \leqq 100 \\
d \leqq 25 \\
3<d \leqq 100\end{array}$ & $\begin{array}{l}\leqq 315 \\
\geqq 225 \\
\geqq 295\end{array}$ & $\begin{array}{c}\geqq 100 \\
- \\
\geqq 245\end{array}$ & $\begin{array}{l}\geqq 20 \\
\geqq 20 \\
\geqq 10\end{array}$ \\
\hline
\end{tabular}

きいが，圧縮されることによりリベットは孔に充満する。こ のように，リベットは過酷な塑性変形を受ける。また，使用 される場合には耐食性も必要であることから, 本研究では, リベット材として A2117-T4 の押出棒を用いた。

日本アルミニウム協会が制定したアルミニウム合金土木構 造物設計・製作指針案 ${ }^{3)}$ では，リベット材として A5056BDO, A5N02BD-O および A6061BD-T6 を規定している。これら のアルミニゥム合金ならびに A2117-T4 の化学成分と機械的 性質をそれぞれ Table 1, Table 2 に示す。

リベット材として A2117-T4の押出棒を選定した理由を次 に記す。

(1) Table 1 に示すように, A5056 と A5N02 は $\mathrm{Mg}$ を $3 \%$ 以 上含む。 $3 \%$ 以上の $\mathrm{Mg}$ を含む A5056-O と A $5 \mathrm{~N} 02-\mathrm{O}$ を冷間で 頭成形やかしめ成形して加工硬化させると, 剥離腐食や応力 腐食割れを起こす可能性がある ${ }^{4)}$ 。

（2）A2117 は，2000 系合金の中では $\mathrm{Cu}$ の含有量が少ない ので耐食性がよい。また， Mgの含有量む少ないので，耐応 力腐食割れ性もよい。

(3) Table 2 に示すように, A6061-T6 は伸びが小さいので, 冷間で頭の成形が困難であることが予想される。

（4）Table 2 に示すように，測定された A2117-T4の押出棒 の強度と伸びは，線材である A2117W-T4 に対して JIS H 40405) で規定される規格值より高い。

（5）呼び径 $22 \mathrm{~mm}$ のリベットの軸径は，21.8 22.8 $\mathrm{mm}$ と許 容差が $1 \mathrm{~mm}$ あるので ${ }^{6)}$, 素材に引抜線を使う必要はなく押 出棒で十分である。

2000 系アルミニウム合金は自然時効硬化を起こす。A2117T4 の押出棒の, 溶体化処理後のビッカース硬さの変化を Fig. 1 に示す。A2117-T4 の硬さは約 150 時間で最高に達する。 Table 2 に示す A2117-T4 の押出棒の機械的性質は，押出棒を 製造してから 150 時間以上経過後の測定值である。

\section{2 リベットの製作と機械的性質}

リベットの規格には，JIS B 1213 「冷間成形リベット」と

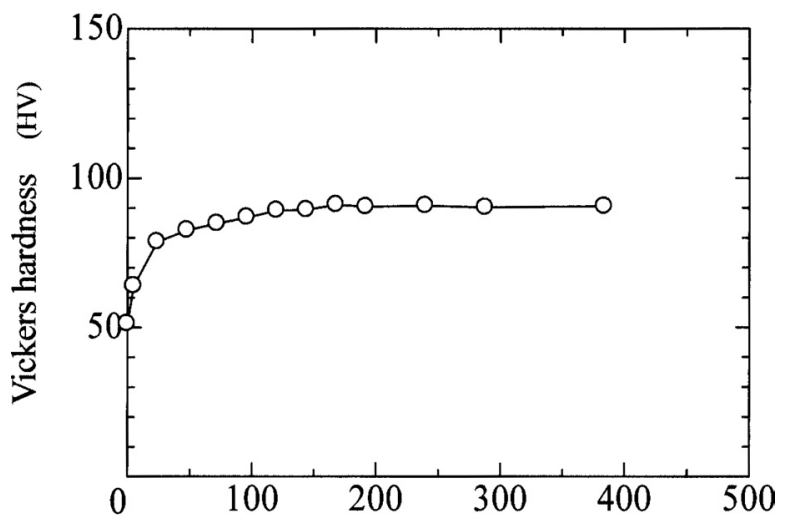

(h)

Fig. 1 Natural aging of A2117-T4.

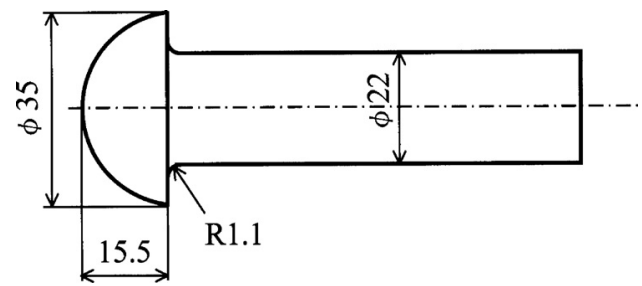

Fig. 2 Dimensions of rivet.

JIS B 1214「熱間成形リベット」があり，アルミニウム合金製 リベットは前者に規定されている。ここでいう冷間成形とは， リベット製作時に, 冷間で頭部を成形することを意味し, 冷 間で被締結部材のかしめ成形を行うことを意味するものでは ない。本研究で対象とした, 軸径が $22 \mathrm{~mm}$ のリベットの形状 を Fig. 2 に示す。リベットの形状は, JIS B 1213 「冷間成形 リベット」で規定される丸リベットの形状に従っている。 製作時に，頭部の成形を冷間で行うには 2 つの方法が考え られる。A2117-T1 の押出棒に冷間で頭部を成形した後 T4 処 


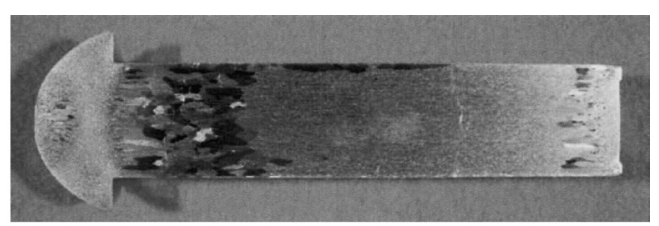

(a)

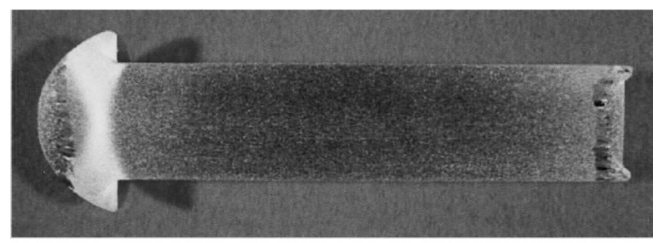

(b)

Fig. 3 Macroscopic structure of rivet. (a) T4 treatment after cold forming, (b) Cold forming after T4 treatment.

Table 3 Measured mechanical properties of completed rivet

\begin{tabular}{c|c|c}
\hline $\begin{array}{c}\text { Tensile strength } \\
(\mathrm{MPa})\end{array}$ & $\begin{array}{c}0.2 \% \text { proof stress } \\
(\mathrm{MPa})\end{array}$ & $\begin{array}{c}\text { Elongation } \\
(\%)\end{array}$ \\
\hline 298 & 172 & 33 \\
\hline
\end{tabular}

理する方法と，A2117-T4 の押出棒に冷間で頭部を成形する方 法である。

2 つの方法で試作したリベットの断面のマクロ組織写真を Fig. 3 (a)，（b）に示す。Fig. 3 (a) は頭部成形後に T4 処理 したリベットの断面のマクロ組織写真, Fig. 3 (b) は T4 処理 後に頭部成形したリベットの断面のマクロ組織写真である。 $\mathrm{T} 4$ 処理の条件は, $495^{\circ} \mathrm{C} に 2$ 時間保持後に水冷である。頭部 の成形時には，成形後にリベットを金型から抜きやすくする ため, ごちらの場合も押出棒を $170^{\circ} \mathrm{C}$ に加熱した。

Fig. 3 (a) では, 首下から若干離れた場所に粗大な結晶が 生じている。この部分には加工ひずみが十分に作用しなかっ たため, T4 処理で核生成が十分でなく, 粗大な再結晶が生 じている。頭の部分には, 大きな加工ひずみが作用したので, $\mathrm{T} 4$ 処理で微細な再結晶が生じている。首下から十分離れた 軸の部分にはほとんど加工ひずみが作用しなかったため, T4 処理によって再結晶は生じていない。粗大結晶が生じたリ ベットを軸方向に圧縮すると, 粗大結晶が生じた箇所の軸表 面の円周各部に軸方向の割れが発生する。Fig. 3 (b) には粗 大な結晶はみられないので, 圧縮を受けても割れは発生しな い。以上から, 本研究では A2117-T4 の押出棒に冷間で頭部 を成形することにした。

製作後のリベットの軸径は 22.3 22.4 mm で, JIS B 12136) で 規定される許容值の $21.8 \sim 22.8 \mathrm{~mm}$ 以内にあった。製作後のリ ベットから採取した試験片の機械的性質を Table 3 に示す。 試験片の形状は, 頭部も含めた全長 $115 \mathrm{~mm}$ のリベットから 削り出した, 全長 $115 \mathrm{~mm}$, 平行部の長さおよび直径がそれ ぞれ $40 \mathrm{~mm}, 6 \mathrm{~mm}$ の JIS $14 \mathrm{~A}$ 号試験片である。製作後のリ ベットの引張強さと伸びは, Table 2 に示す A2117-T4 押出棒 とほぼ同じである。

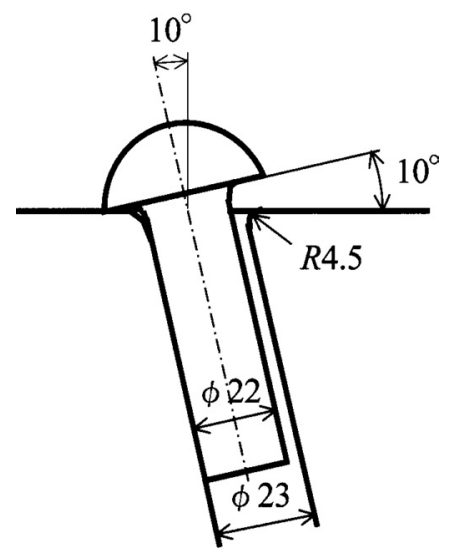

Fig. 4 Test of head toughness.

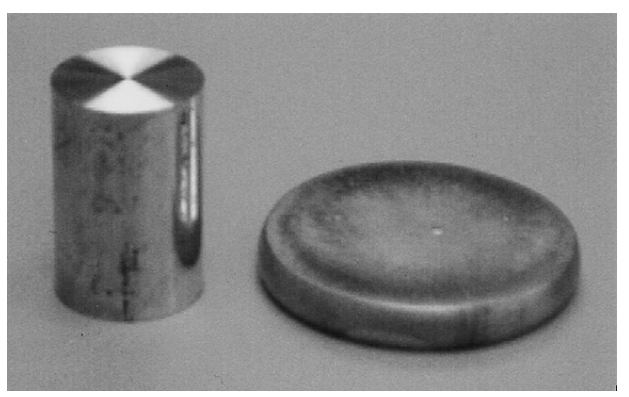

Fig. 5 Specimens before and after test of shank toughness.

\section{3 リベットに要求されるじん性}

JIS B 1213 「冷間成形リベット」に従って, リベットの頭部 と軸部のじん性を調べた。頭部に要求されるじん性は, Fig. 4 に示すように, 垂直線に対して 10 度傾斜した試験用治具の 孔にリベットを差し込み, 座面が平面に密着するまで常温で 頭部を打撃した後, 頭部と軸部との付け根に切損, 首下丸み 部に割れがあってはならない。

軸部に要求されるじん性は, リベットの軸部から, 軸部の 直径の 1.5 倍の長さの試験片を採取し, 長さが軸部の直径の 3 分の 1 になるまで常温で軸心方向に圧縮を加えた後, 扁平 になった試験片の周辺に割れが生じてはならない。本研究で は, 軸部の直径が $22 \mathrm{~mm}$ であるので, 長さが $33 \mathrm{~mm}$ の丸棒 を，長さが $7.3 \mathrm{~mm}$ まで圧縮することになる。

試験の結果，頭部および軸部に切損や割れはみられず，リ ベットに要求されるじん性が満たされている。両試験結果の うち，軸部の結果を Fig. 5 に示す。

\section{3. アルミニウム合金製リベットのかしめ}

\section{1 リベットの孔とかしめ頭の形状}

本研究で用いたリベット材 A2117-T4 と同程度の機械的性 質を有する A5056-O のリベットを加熱後, リベッティング八 ンマでかしめ成形する方法では, リベットの軸部の直径が $20 \mathrm{~mm}$ 以上になると, かしめ成形することができない7)。そ こで, リベットによる被締結材のかしめは, 冷間の状態でプ レス機により行った。リベットのかしめ頭としては, 一般に 半球頭または平頭が用いられる。半球頭の成形荷重は, 平頭 のそれの 2 倍以上高くなるので ${ }^{8}$, 本研究では, プレス機の 容量を下げるために平頭を採用した。

リベットの孔径と平頭の形状については, 米国アルミニウ 
ム協会が制定した AA 基準 ${ }^{9)}$ に規定されている。リベットの 呼び径を $d$ とすると, $\mathrm{AA}$ 基準では, 冷間でかしめる場合の リベット孔径は $1.04 d$ 以下，平頭の直径は $1.4 d$ 以上，高さは $0.4 d$ 以上と規定されている。本研究で対象とするリベットの 呼び径は $22 \mathrm{~mm}$ であるので, リベット孔径は $22.88 \mathrm{~mm}$ 以下, 平頭の直径は $30.8 \mathrm{~mm}$ 以上, 高さは $8.8 \mathrm{~mm}$ 以上になる。以上 から, Fig. 6 に示すリベット孔径 $d_{1}$ を $22.8 \mathrm{~mm}$ ，かしめ頭の 直径 $D$ を $32 \mathrm{~mm}$, 高さ $H$ を $10 \mathrm{~mm}$ とした。Fig. 6 において, かしめる板を上から順に上板，中板，下板と呼ぶ。

\section{2 かしめ試験}

リベットの孔への充満度を調べるために，Fig. 7 (a) に示 すように，アルミニウム板を 3 枚重称，それらを Fig. 7 (b) に示すように，3本のリベットでかしめた。アルミニウム板

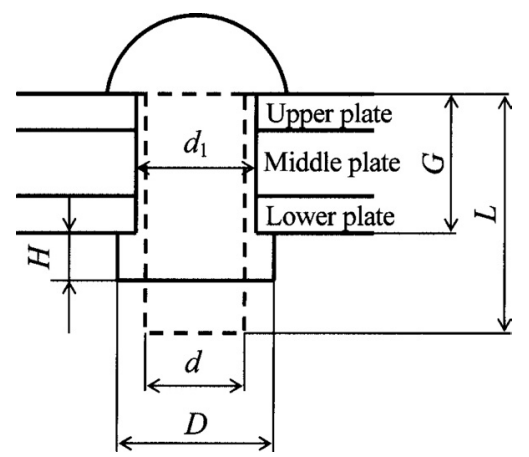

Fig. 6 Cross section of riveted joint.

Table 4 Aluminum alloy and thickness of riveted plates

\begin{tabular}{c|c|r|c}
\hline \hline \multirow{2}{*}{$\begin{array}{c}\text { Aluminum } \\
\text { alloy }\end{array}$} & \multicolumn{2}{|c|}{$\begin{array}{c}\text { Thickness } \\
(\mathrm{mm})\end{array}$} & $\begin{array}{c}\text { Total thickness } \\
(\mathrm{mm})\end{array}$ \\
\cline { 2 - 4 } & $t_{1}$ & $t_{2}$ & $G=2 t_{1}+t_{2}$ \\
\hline \multirow{2}{*}{ A5083P-0 } & 4 & 8 & 16 \\
& 8 & 15 & 31 \\
\hline \multirow{2}{*}{ A6061P-T6 } & 4 & 8 & 16 \\
& 8 & 15 & 31 \\
\hline
\end{tabular}

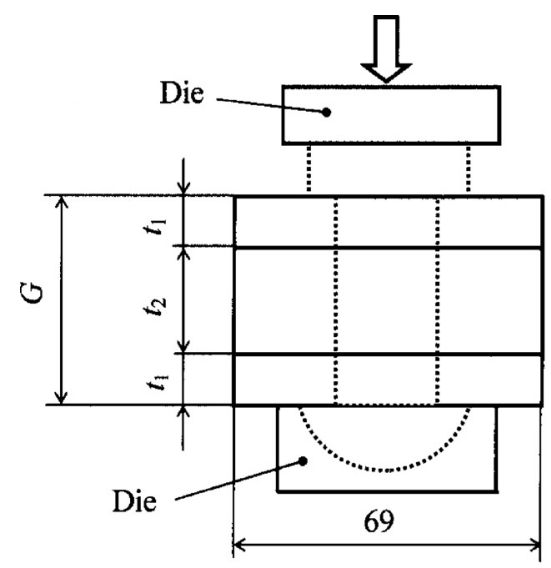

(a)
は，3枚ともに A5083P-O および A6061P-T6 の 2 種類である。 かしめ厚さは $16 \mathrm{~mm}$ と $31 \mathrm{~mm}$ の 2 種類である。板の材質と調 質および板厚を Table 4 に示す。使用した被締結材である A5083P-O と A6061P-T6 の機械的性質を Table 5 に示す。

リベットをかしめる場合のリベットの首下長さ $L$ は，かし め厚さを $G$ として, Fig. 6 のかしめ前の破線部の体積とかし め後の軸部と頭部の体積が等しいという条件から, 次式より 求めた。

$$
L=\frac{d_{1}^{2} G+D^{2} H}{d^{2}}
$$

この式から求められるかしめ厚さ $16 \mathrm{~mm}$ と $31 \mathrm{~mm}$ に対する リベット首下長さは，それぞれ $38.3 \mathrm{~mm} ， 54.5 \mathrm{~mm}$ になる。リ ベットの首下をこれらの長さに切断し，孔にリベットを挿入

Table 5 Measured mechanical properties of plates (JIS 14B specimen)

\begin{tabular}{c|c|c|c|c}
\hline \hline $\begin{array}{c}\text { Aluminum } \\
\text { alloy }\end{array}$ & $\begin{array}{c}\text { Thickness } \\
(\mathrm{mm})\end{array}$ & $\begin{array}{c}\text { Tensile } \\
\text { strength } \\
(\mathrm{MPa})\end{array}$ & $\begin{array}{c}0.2 \% \text { proof } \\
\text { stress } \\
(\mathrm{MPa})\end{array}$ & $\begin{array}{c}\text { Elongation } \\
(\%)\end{array}$ \\
\hline & 4 & 317 & 150 & 23 \\
A5083P-0 & 8 & 303 & 147 & 28 \\
& 15 & 300 & 148 & 29 \\
\hline & 4 & 331 & 291 & 14 \\
A6061P-T6 & 8 & 297 & 266 & 17 \\
& 15 & 327 & 298 & 21 \\
\hline
\end{tabular}

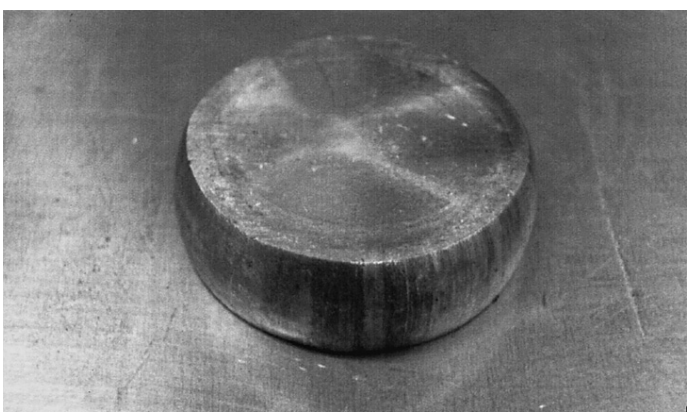

Fig. 8 Pressed head of rivet.

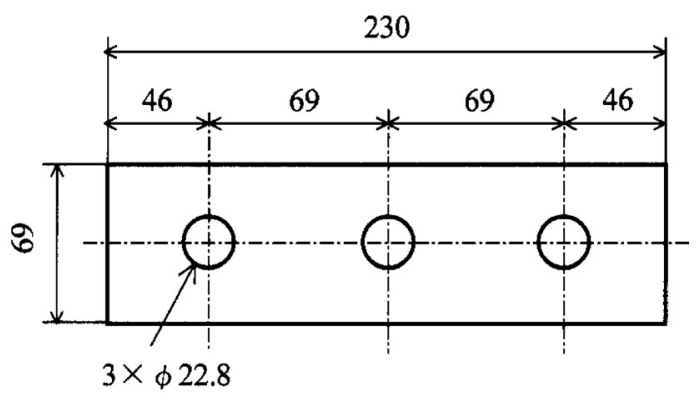

(b)

Fig. 7 Riveted plates. (a) Thickness of plates, (b) Dimension of plates. 


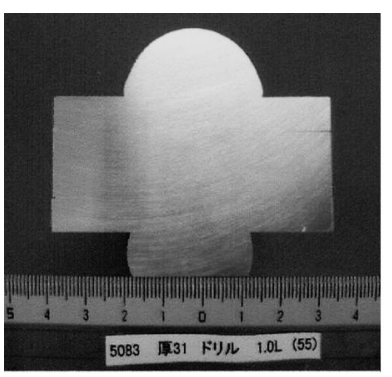

(a)

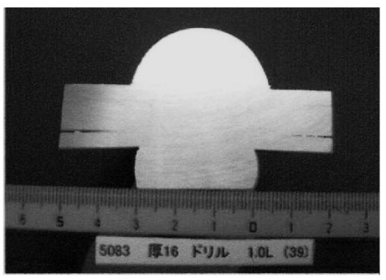

(b)

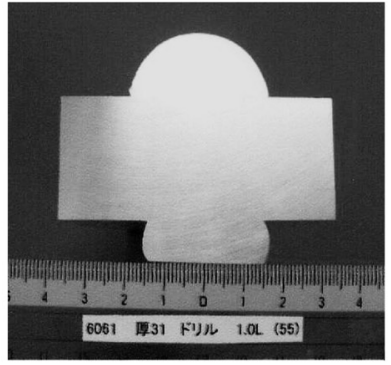

(c)

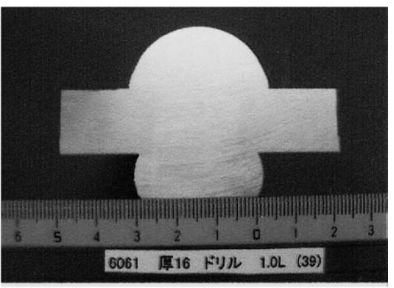

(d)

Fig. 9 Cross section of riveted plates. (a) A5083P-O Total thickness $31 \mathrm{~mm}$, (b) A5083P-O Total thickness 16 mm, (c)A6061P-T6 Total thickness $31 \mathrm{~mm}$, (d) A6061P-T6 Total thickness $16 \mathrm{~mm}$

Table 6 Measured values of diameter of pressed head

\begin{tabular}{c|c|c|c|c}
\hline \hline \multirow{2}{*}{$\begin{array}{c}\text { Aluminum } \\
\text { alloy }\end{array}$} & \multirow{2}{*}{$\begin{array}{c}\text { Total } \\
\text { thicknes } \\
\text { (mm) }\end{array}$} & \multicolumn{3}{|c}{$\begin{array}{c}\text { Head diameter at middle plate } \\
\text { (mm) }\end{array}$} \\
\cline { 3 - 5 } & & Left & Center & Right \\
\cline { 3 - 5 } & 16 & 31.9 & 31.9 & 32.0 \\
\hline \multirow{2}{*}{ A5083P-0 } & 31 & 31.7 & 31.7 & 31.7 \\
& 16 & 32.4 & 32.3 & 32.3 \\
A6061P-T6 & 31 & 31.6 & 32.4 & 31.9 \\
\hline
\end{tabular}

Table 7 Measured enlargement of rivet hole

\begin{tabular}{|c|c|c|c|c|}
\hline \multirow{2}{*}{$\begin{array}{l}\text { Aluminum } \\
\text { alloy }\end{array}$} & \multirow{2}{*}{$\begin{array}{l}\text { Thickness } \\
\text { (mm) }\end{array}$} & \multicolumn{3}{|c|}{$\begin{array}{l}\text { Dimensions on hole after riveting } \\
(\mathrm{mm})\end{array}$} \\
\hline & & Plate & Diameter & Enlargement \\
\hline \multirow{2}{*}{ A5083P-O } & 16 & $\begin{array}{l}\text { Upper } \\
\text { Middle } \\
\text { Lower }\end{array}$ & $\begin{array}{l}22.9 \\
24.0 \\
24.6\end{array}$ & $\begin{array}{l}0.1 \\
1.2 \\
1.8\end{array}$ \\
\hline & 31 & $\begin{array}{l}\text { Upper } \\
\text { Middle } \\
\text { Lower }\end{array}$ & $\begin{array}{l}23.1 \\
23.6 \\
24.7\end{array}$ & $\begin{array}{l}0.3 \\
0.8 \\
1.9\end{array}$ \\
\hline \multirow{2}{*}{ A6061P-T6 } & 16 & $\begin{array}{l}\text { Upper } \\
\text { Middle } \\
\text { Lower }\end{array}$ & $\begin{array}{l}23.0 \\
23.2 \\
23.5\end{array}$ & $\begin{array}{l}0.2 \\
0.4 \\
0.7\end{array}$ \\
\hline & 31 & $\begin{array}{l}\text { Upper } \\
\text { Middle } \\
\text { Lower }\end{array}$ & $\begin{array}{l}23.1 \\
23.3 \\
23.6\end{array}$ & $\begin{array}{l}0.3 \\
0.5 \\
0.8\end{array}$ \\
\hline
\end{tabular}

する。Fig. 7 (a) に示すように, リベットの球形の頭を金型 で支え，反対側のリベット軸先端を平らな金型で，高さが $10 \mathrm{~mm}$ になるまで圧縮してかしめ頭を成形する。かしめ頭の 成形荷重は，かしめ厚さが $16 \mathrm{~mm}$ の場合に $500 \mathrm{kN}, 31 \mathrm{~mm}$ の 場合に $550 \mathrm{kN}$ であった。成形されたかしめ頭を Fig. 8 に示 す。かしめ部の断面を Fig. 9 に示す。リベットは孔に充満し ていることがわかる。

かしめ頭の直径の測定結果を Table 6 に示す。かしめ頭の

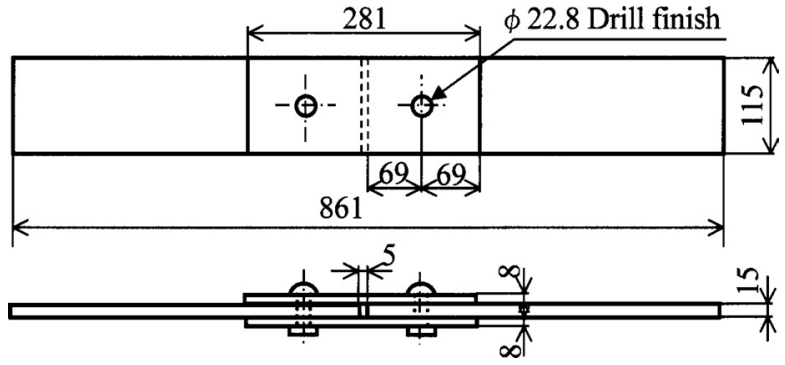

Fig. 10 Specimen for static tensile shearing test.

高さの測定值はすべて $10 \mathrm{~mm}$ であった。重ねた 3 枚の板の各 板の板厚中央に扫けるリベット孔の拡がりの測定結果を Table 7 に示す。Fig. 9 および Table 6, Table 7 から次のこと がわかる。

（1）被かしめ材の材質に関して

A5083P-O では, かしめ頭が板に陷没し，板が面外に曲が る挙動が観察される。この挙動は板厚が薄い方が顕著である。 A6061P-T6では，このような挙動は観察されない。リベット のかしめによる孔の拡がりは, A6061P-T6 より A5083P-O の方 が大きい。このため，かしめ頭の径は A6061P-T6より A5083P-O が小さい。これらは, A5083P-O の 0.2\% 耐力が A6061P-T6 のそれより低いためである。

(2) かしめ厚さに関して

かしめ頭の径とかしめによる孔の拡がりに対して, かしめ 厚さの違いによる影響は小さい。

（3）かしめ厚さ方向のリベット孔径に関して

孔の拡がりは, Fig. 6 に示す上板, 中板, 下板の順で大き くなる。これは, かしめ頭側の材料の半径方向の拘束が緩い ためである。中板の径の拡がりは, A5083P-O では $1.0 \mathrm{~mm}$, A6061P-T6 では $0.5 \mathrm{~mm}$ である。前者の径の拡がりは, 後者の 2 倍である。これは, A5083P-O の 0.2\% 耐力が A6061P-T6 の それより低いためである。

\section{4. アルミニウム合金製リベットのせん断強さとせん 断疲労強度}

\section{1 せん断強さ}

本研究で開発した 2117 アルミニウム合金製リベットのせん 断強さを明らかにするために, 静的引張せん断試験を行った。 試験片の形状と寸法を Fig. 10 に示す。試験片の全長と幅は それぞれ $861 \mathrm{~mm}, 115 \mathrm{~mm}$, 母材の板厚は $15 \mathrm{~mm}$, 添接板の 板厚は $8 \mathrm{~mm}$ で，厚さの合計は $31 \mathrm{~mm}$ である。 
Table 8 Measured mechanical properties of specimens for shear tests (JIS 14B specimen)

\begin{tabular}{c|c|c|c|c}
\hline \hline $\begin{array}{c}\text { Aluminum } \\
\text { alloy }\end{array}$ & $\begin{array}{c}\text { Thickness } \\
(\mathrm{mm})\end{array}$ & $\begin{array}{c}\text { Tensile } \\
\text { strength } \\
(\mathrm{MPa})\end{array}$ & $\begin{array}{c}0.2 \% \text { proof } \\
\text { stress } \\
(\mathrm{MPa})\end{array}$ & $\begin{array}{c}\text { Elongation } \\
(\%)\end{array}$ \\
\hline A5083P-0 & 8 & 314 & 154 & 25 \\
& 15 & 306 & 148 & 22 \\
\hline A6061P-T6 & 8 & 340 & 324 & 17 \\
& 15 & 329 & 300 & 15 \\
\hline
\end{tabular}

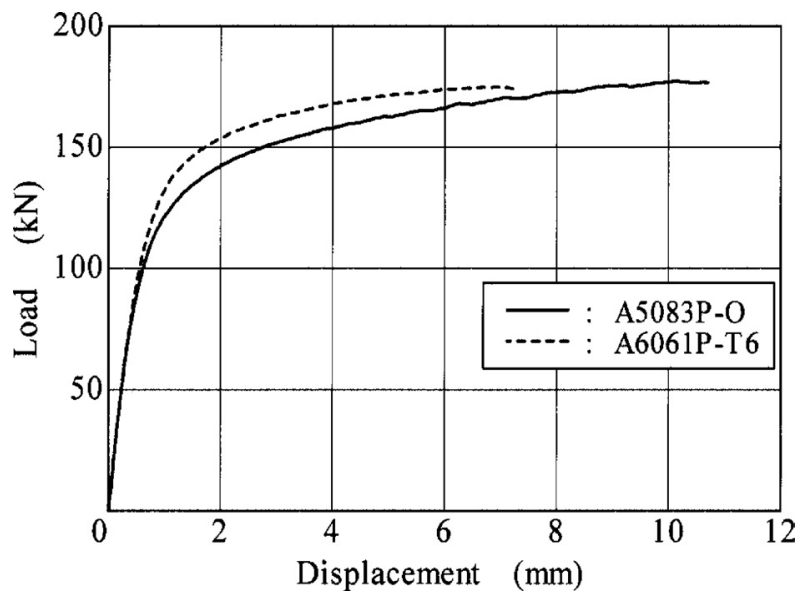

Fig. 11 Relation between load and displacement.

アルミニウム合金土木構造物設計・製作指針案 3) では，母 材抒よび添接板の材端之材縁が破壊しないように，リベット 孔の中心から材端までの距離抒よびリベット孔の中心から材 縁までの距離をそれぞれ 2 倍以上，1.5 倍以上とるよう規定 している。したがって, Fig. 10 に示すように, リベット孔の中 心から材端までの距離を $69 \mathrm{~mm}$, リベット孔の中心から材縁 までの距離を $57.5 \mathrm{~mm}$ としている。リベット孔は, 直径 $22.8 \mathrm{~mm}$ のドリル仕上げである。母材と添接板の材料には A5083P-O と A6061P-T6 を用いた。これらの材料の機械的性 質を Table 8 に示す。試験片は各 3 体である。

荷重と変位の関係の例を Fig. 11 に示す。変位は, 試験片 の中央から $150 \mathrm{~mm}$ ずつ離れた添接板を挟んだ $300 \mathrm{~mm}$ 間の值 である。Fig. 11 からわかるように, 荷重と变位の関係が初期 から直線的に立ち上がっているので, リベットは孔に充満し ている。

試験片は，すべて Fig. 12 に示すように，リベットのせん 断破壊で破断した。リベットがせん断破壊したときの荷重お よび，そのときのリベットに生じるせん断応力，すなわち， リベットのせん断強さを Table 9 に示す。ここで, リベット のせん断強さは次式から計算される。

$$
\tau_{\mathrm{B}}=P_{\mathrm{B}} /\left(2 A_{\mathrm{h}}\right)
$$

ここで, $\tau_{\mathrm{B}}$ : リベットのせん断強さ

$P_{\mathrm{B}}$ : リベットがせん断破壊したときの荷重

$A_{\mathrm{h}}$ : リベット孔の断面積

式（2）において, リベット孔の断面積を 2 倍にしている のは, Fig. 12 に示すように, 上板と中板との界面の位置およ

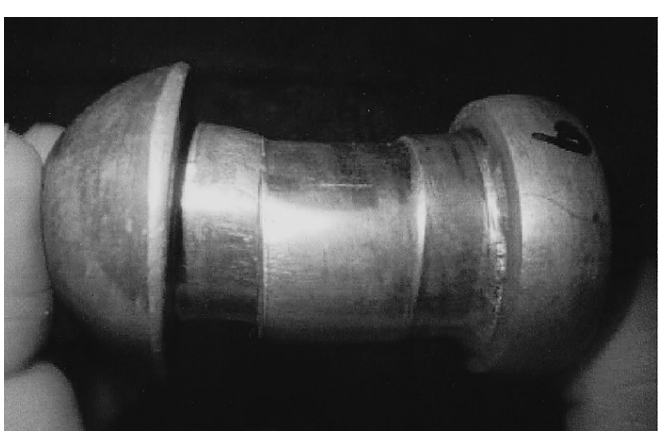

Fig. 12 Broken rivet due to shear.

Table 9 Shear strength of rivets

\begin{tabular}{|c|c|c|c|c|}
\hline \multicolumn{2}{|c|}{ Specimen } & \multirow{2}{*}{$\begin{array}{c}\text { Load at } \\
\text { failure } \\
P_{\mathrm{B}}(\mathrm{kN})\end{array}$} & \multirow{2}{*}{$\begin{array}{c}\text { Shear strength } \\
\text { of rivet } \\
\tau_{\mathrm{B}}(\mathrm{MPa})\end{array}$} & \multirow[b]{2}{*}{$\tau_{\mathrm{B}} / \sigma_{\mathrm{I}}$} \\
\hline $\begin{array}{l}\text { Aluminum } \\
\text { alloy }\end{array}$ & No. & & & \\
\hline \multirow{4}{*}{ A5083P-O } & 1 & 176 & 216 & 0.72 \\
\hline & 2 & 176 & 216 & 0.72 \\
\hline & 3 & 178 & 218 & 0.73 \\
\hline & Mean & 177 & 217 & 0.73 \\
\hline \multirow{4}{*}{ A6061P-T6 } & 1 & 168 & 206 & 0.69 \\
\hline & 2 & 170 & 208 & 0.70 \\
\hline & 3 & 173 & 212 & 0.71 \\
\hline & Mean & 170 & 208 & 0.70 \\
\hline
\end{tabular}

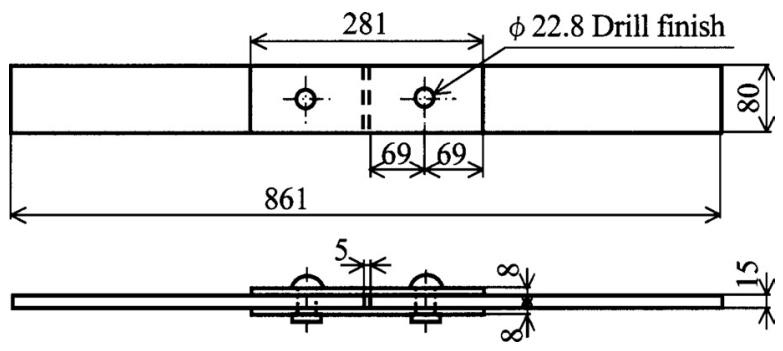

Fig. 13 Specimen for fatigue.

び中板と下板との界面の位置, すなわち 2 つの界面の位置で リベットがせん断力に抵抗しているからである。また，リ ベットの抵抗断面積としてリベットの軸径に関する断面積で なく, リベット孔に関する断面積を採用しているのは, 前述 したように，リベットが孔に充満しているからである。

リベットの引張強さ $\sigma_{\mathrm{B}}$ (Table 3 参照) に対するせん断強 さ $\tau_{\mathrm{B}}$ の比，すなわち $\tau_{\mathrm{B}} / \sigma_{\mathrm{B}}$ の值を Table 9 に示す。この值は, 試験片が A5083P-O の場合 0.73, A6061P-T6 の場合 0.70 であ る。鋼製の母材と添接板を鋼製リベットで接合した場合, 鋼 製リベットの $\tau_{\mathrm{B}} / \sigma_{\mathrm{B}}$ が 0.75 になることが実験的に明らかにさ れている ${ }^{10)}$ 。ただし, この場合, リベットの抵抗断面積とし て, リベットの軸径に関する断面積が採用されている。リ ベットの抵抗断面積の採り方に違いがあるが，アルミニウム 合金製リベットの $\tau_{\mathrm{B}} / \sigma_{\mathrm{B}}$ は鋼製リベットのそれに近い。

\section{2 せん断疲労強度}

本研究で開発した 2117 アルミニウム合金製リベットのせん 断疲労強度を明らかにするために, Fig. 13 に示す試験片に 
Table 10 Results of fatigue test $($ Stress ratio $=0.1$ )

\begin{tabular}{c|c|c|c}
\hline \hline Specimen & $\begin{array}{c}\text { Number } \\
\text { of cycles } N\end{array}$ & $\begin{array}{c}\text { Load range } \\
\Delta P(\mathrm{kN})\end{array}$ & $\begin{array}{c}\text { Shear stress range } \\
\Delta \tau(\mathrm{MPa})\end{array}$ \\
\hline 1 & $5.04 \times 10^{4}$ & 128.7 & 158 \\
2 & $2.23 \times 10^{5}$ & 121.2 & 148 \\
3 & $2.37 \times 10^{6}$ & 84.6 & 104 \\
4 & $2.12 \times 10^{6}$ & 77.5 & 95 \\
5 & $7.40 \times 10^{6}$ & 65.2 & 80 \\
\hline
\end{tabular}

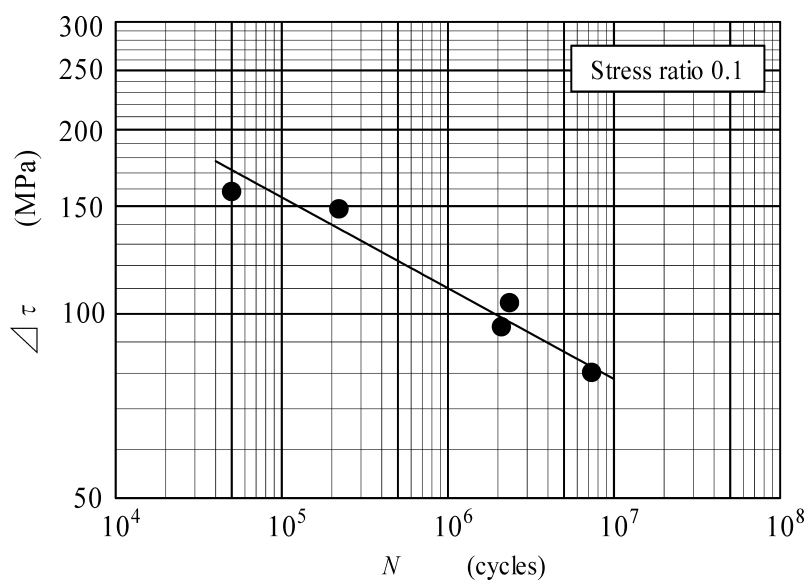

Fig. 14 S-N curve.

対して引張せん断疲労試験を行った。疲労試験機の能力のた めに, 試験片の幅が, 静的引張せん断試験の場合の試験片 (Fig. 10 参照) の幅より小さくなっている。応力比が 0.1 で疲 労試験を実施した。

母材と添接板が A5083P-O の試験片では, リベットではな くて母材が疲労で破断した。母材と添接板が A6061P-T6 の試 験片では，リベットがせん断疲労で破壊した。長寿命領域の デー夕を採取していないので, 疲労限については考察ができ ない。この結果を Table 10 に示す。ここで, せん断応力範 囲 $\Delta \tau$ 之荷重範囲 $\Delta P$ は次式から計算される。

$$
\Delta \tau=\Delta P /\left(2 A_{\mathrm{h}}\right)
$$

$\Delta \tau$ と $N$ の関係を S-N 関係で表すと Fig. 14 になる。 $\log (\Delta \tau)$ を独立变数, $\log N$ を従属变数として, 最小二乗法によって 決定されたリベットの S-N 曲線が次式で与えられる。

$$
\Delta \tau=861 \times N^{-0.1486}
$$

この式から, 繰返し回数 $10^{7}$ に対するリベットの疲労強度 は $78 \mathrm{MPa}$ である。

\section{5. 結言}

社会基盤構造物にアルミニウム合金を適用するために, 軸 径 $22 \mathrm{~mm}$ の大径アルミニウム合金製リベットを開発し, リ ベット継手試験片によりそのせん断強さとせん断疲労強度を 明らかにした。主な結論は次の通りである。

（1）冷間成形アルミニウム合金製リベット材として A2117$\mathrm{T} 4$ の押出棒を, T4 処理後に頭部の成形を行うことにより, 粗大な結晶が生じないリベットを製作することができる。

（2）A2117-T4 の押出棒で製作されたアルミニウム合金製リ ベットは, JIS B 1213 「冷間成形リベット」に規定される, 頭 部および軸部に対するじん性要求を満足する。

（3）A2117-T4 のアルミニゥム合金製リベットに関して，リ ベット孔径を $22.8 \mathrm{~mm}$, 径と高さがそれぞれ $32 \mathrm{~mm}, 10 \mathrm{~mm}$ の 平頭のかしめ頭で, 冷間で, プレスにより, リベットを孔に 充満させることができる。

（4）A2117-T4 のアルミニウム合金製リベットに関して，か しめ前のリベットの引張強さに対する, かしめ後のせん断強 さの比は, 母材と添接板が A5083P-O の場合 0.73, 母材と添 接板が A6061P-T6 の場合 0.70 である。

（5）A2117-T4 のアルミニウム合金製リベットのせん断疲労 に対する S-N 曲線は, 応力比が 0.1 に対して, $\Delta \tau=861 \times$

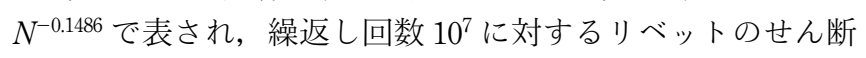
疲労強度は $78 \mathrm{MPa}$ である。

\section{謝 辞}

本研究は, 科学技術振興調整費充当戦略的研究拠点「阪大 フロンティア研究機構」の研究プロジェクト（プロジェクト 名：アルミニウム橋実現のための基礎研究）の下で行われた。

\section{参 考 文 献}

1）大倉一郎, 萩澤亘保, 岩田節雄, 北村幸嗣：アルミニウム橋実 現のための技術開発，軽金属，54（2004），380-387.

2）大倉一郎, 萩澤亘保, 鳴尾 亮, 戸田 均：摩擦摚拌接合で製 作されたアルミニウム床版の疲労特性, 土木学会論文集, No. 703/I-59, (2002), 255-266.

3）日本アルミニウム協会：アルミニウム合金土木構造物設計・製 作指針案 (第 1 次改訂試案), (2000).

4）軽金属学会：アルミニウムの組織と性質，（1991），271.

5）日本工業規格：JIS H 4040, アルミニウム及びアルミニウム合金 の棒及び線, (1999).

6）日本工業規格：JIS B 1213，冷間成形リベット，（1995).

7）日本アルミニウム協会：平成 11 年度材料関連知的基盤整備受 託成果報告書 アルミニウム材料の接合特性データの整備, (2001), 43-62.

8) The Aluminum Association: Aluminum Design Manual, Part VII, Design Aids, (2000), 100.

9) The Aluminum Association: Aluminum Design Manual, Part I A, Specifications for Aluminum Structures-Allowable Stress Design, (2000), 64 .

10） G. L. Kulak, J. W. Fisher and J. H. A. Struik: Guide to Design Criteria for Bolted and Riveted Joints, A Wiley-Interscience Publication, (1987), 33. 